\title{
HATOUM, Milton. Dois irmãos. São Paulo: Companhia das Letras, 2000.
}

\author{
Denis Leandro Francisco \\ Universidade Federal de Minas Gerais
}

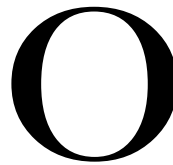

utra casa se desfaz em Dois irmãos, segundo livro do escritor amazonense Milton Hatoum, publicado em 2000. A epígrafe de versos drummondianos que abre o texto já anuncia a encenação de um drama familiar cujo palco é a casa desfeita e repleta de lembranças, sonhos, também pesadelos e outros imponderáveis.

A tumultuada e irreconciliável relação dos irmãos gêmeos Yaqub e Omar é o fio com o qual Hatoum tece tramas distintas que entrecruzam-se em fortes significações. A disputa entre os gêmeos aparece como conflito entre o sul e o norte do país: Omar, filho caçula e dileto de Zana - e que traz no nome um conveniente anagrama de 'amor' - está para o mormaço e o atraso amazônicos assim como Yaqub, o engenheiro de futuro sempre promissor, está para o desenvolvimento vertiginoso de
São Paulo e do sul do país. O roteiro quase previsível de dois irmãos que, sendo gêmeos, não se harmonizam é perturbado positivamente pelo trabalho cuidadoso com a prosa e a estrutura narrativa, ainda que esta não apresente as interessantes interpolações temporais e as várias vozes dialogizantes do primeiro romance do autor.

Manaus surge em meio a essa fabulação como um mundo em trânsito entre o rio Negro e a floresta Amazônica, entre o Ocidente e o Oriente. Com efeito, uma das perspectivas de Dois irmãos é a do diálogo que se estabelece entre a decadência e ruína de uma família de imigrantes libaneses e a degradação da cidade de Manaus, que passa da pacatez à azáfama da industrialização após o advento da Zona Franca na década de 60. A decadência da cidade apresenta-se, no romance, como ressonância da 
decadência da família quando o norte começa a imitar o sul no que ele tem de produtivo e de desastroso: uma amostra da indústria e do progresso da metrópole é enviada por Yaqub, atravessa o país e estaciona na porta da casa de Zana enquanto Rânia, a filha mais nova, inicia a empreendedora modernização da antiga loja do pai. Nessa época, "Yaqub e o Brasil inteiro pareciam ter um futuro promissor" (p.41) e o filho mais velho, vestindo "a máscara do que havia de mais moderno no outro lado do Brasil" (p.61), torna-se um renomado engenheiro. Mas o futuro é essa "falácia que persiste" (p.263) e o destino do próspero Yaqub, inesperadamente, irá confundir-se com o do arcaico Omar.

A casa que agoniza juntamente com as histórias às quais serve de morada diz também de uma narrativa que, sobretudo modernamente, encontra-se em constante interrogação acerca de suas possibilidades: o sentido da enunciação evidencia-se pela dimensão metalingüística do romance, dimensão repetidamente explorada no texto, tanto tematica quanto estruturalmente, sobretudo quando, ao final, o romance revelase um conjunto de anotações e escritos do narrador.

$\mathrm{Na}$ voz do narrador Nael, filho da empregada Domingas e de um dos gêmeos, ouvem-se ecos de um debate sobre a figura do intelectual ou daquele que se debruça sobre a escrita e seus imprevisíveis meandros. É essa personagem, sempre deslocada no espaço da casa e relegada ao quarto dos fundos, quem irá se distanciar e se elevar acima das histórias ouvidas ou presenciadas para, de longe, narrálas anos após o desmoronamento da casa. Antes da ruína, o narrador já havia se aventurado na tentativa de escrever sobre o passado, mas este encontrava-se, então, demasiado próximo e, em sua constrangedora proximidade, não se permitia capturar pela linguagem porque as "palavras parecem esperar a morte e o esquecimento; permanecem soter-radas, petrificadas, em estado latente, para depois, em lenta combustão, acenderem em nós o desejo de contar passagens que o tempo dissipou." (p.244).

O salto pessoal que mais tarde efetuará o narrador-personagem se dá por meio das muitas e incansáveis leituras que para ele se sobrepõem ao mundo das mercadorias - que não era o seu, nunca foi - e que no futuro farão dele um professor. É desse lugar da perda, de uma casa já em ruínas que se intenta recuperar a memória e suas histórias; mas, a despeito do tom melancólico com o qual o narrador narra sua história e que perpassa todo o romance, percebe-se que essa enunciação em ruínas aponta 
também para o que há de positivo em sua dimensão arruinada, pois é graças à ruína que se abrem possibilidades de retomada e de reconstrução: a transformação do menino Nael nesse escritor de memórias insinua um viés otimista em relação ao tempo, seu desfacelameto e retomada pelo gesto da escrita: o oprimido leitor de outrora é agora um narrador-escritor, alguém capaz de converter experiência em matéria romanesca pelo trabalho associado entre memória e linguagem.

Qual um artesão sedento de lembranças, sedento "de um passado desconhecido, jogado sei lá em que praia de rio" (p.91), o narrador vai recompondo retalhos desse tecido esgarçado que é a memória através das histórias repletas de lacunas que ouve, principalmente, do velho avô Halim e de sua mãe Domingas, até reconstituir o tecido - mas somente após urdi-lo em outra e nova trama, pois que "a memória inventa, mesmo quando quer ser fiel ao passado." (p.90).

Em sua urdidura, o narrador irá esbarrar em silêncios e em vãos próprios da rememoração, pois que um silêncio excessivo participa da narrativa e persegue várias das personagens: Yaqub, o filho preterido e que teve sua infância interrompida bruscamente, enviado que foi ao Líbano na tentativa desesperada de apaziguar os dois irmãos, converte-se em uma figura silenciosa e esquiva que se cala sobre tudo, inclusive sobre o episódio de uma emblemática cicatriz causada pelo irmão, assim como sobre a sua verdadeira ligação com Domingas e seu filho. Qual um réptil, uma "minhoca que se quer serpente" (p.61), o irmão mais velho desliza silenciosamente por entre a folhagem para, ao final, dar o derradeiro bote. Contudo, o determinado homem de cálculos permanece, após o regresso, sempre algo deslocado, como se não mais pertencesse àquele espaço, àquela casa; não exatamente um estranho, "mas alguém que não conseguia ser espontâneo na casa onde nascera." (p.112). E tudo nele, seu interesse em redescobrir pessoas, paisagens, cheiros e sabores de outro lugar, outro tempo, "era logo sufocado pela lembrança de uma ruptura" (p.116) e o silêncio quanto a esse corte - lembremo-nos da cicatriz ele o carrega consigo: sua frase sempre incompleta, sua reticência permanente, seu silêncio que permanece como incessante ruído. O silêncio do filho mais velho desdobra-se em outros silêncios no interior da narrativa: no silêncio de Domingas, a empregada meio escrava, meio ama e "louca para ser livre" (p. 67), como confessou ao filho, mas cuja voz submerge à da patroa e silencia. Sonhando com 
uma liberdade para sempre adiada, Domingas passa a vida a relembrar o lugar onde nascera, "o seu lugar", como costumava dizer, e nunca se esqueceu dos pássaros que viviam perto do povoado de São João, na margem do Jurubaxi, seus sons e nomes; ou no silêncio de Halim, que esquece, quem sabe se propositadamente, passagens do passado e preenche-as com omissões e lacunas, talvez num desejo secreto de esquecer a tristeza de ter perdido, para o filho mais novo, muito da vida que ansiava partilhar a sós com a esposa.

Em Dois irmãos, Manaus estará sempre associada à imagem do porto flutuante, um porto como metáfora às identidades, também flutuantes, representadas no romance. A verdade sobre sua origem, o próprio narrador prefere adiar indefinidamente: "Adiei a pergunta sobre o meu nascimento. Meu pai. Sempre adiaria, talvez por medo." (p.133), adiamento que é também mantido pelo mútuo e cúmplice silêncio entre Yaqub e Domingas. A exatidão sobre a identidade do sujeito narrador permanece em suspenso, não se esclarece por inteiro na narrativa, ao contrário e muito a propósito, essa questão é deixada em aberto pelo autor, qual um cais de porto: esse espaço sempre aberto a novas chegadas e partidas, lugar de passagem e do provisório, não de permanência.

Ao final do romance, a casa em ruínas, esvaziada e envelhecida de Dois irmãos encontra-se, na figura da matriarca Emilie, com uma outra casa arruinada, a de Relato de um certo Oriente, primeiro romance de Milton Hatoum e, nesse encontro, pode-se ler o desejo recorrente de vasculhar as inconclusões do passado, evidenciando o caráter de mito pessoal que a imagem da casa que se desfaz parece delinear no universo ficcional do autor. 